\title{
SOUTHERN BRAZILIAN JOURNAL OF CHEMISTRY
}

\author{
SOUTH. BRAZ. J. CHEM., Vol.4 N²4, 1996
}

\section{MICELLAR CATALYZED HYDROLYSIS OF LITHIUM $p$-NITROPHENYL ETHYL PHOSPHATE (LiPNEF) AND THE PSEUDO PHASE ION EXCHANGE MODEL}

\section{Lavinel G. Ionescu*}

Instituto de QuT̃mica, Pontifícia Universidade Catōica do

Rio Grande do Sul, Porto Alegre, RS BRASIL 90619-900 \&

Departamento de Quimica, Centro de Ciências Naturais e Exatas,

Universidade Luterana do Brasil, Canoas, RS BRASIL 92420-280

$$
\&
$$

Danil A. R. Rubio, Departamento de Química, Universidade

Estadual de Maringā, Maringā, PR BRASIL

\&

Elizabeth Fätima De Souza, Instituto de Ciências Biolögicas

e Químicas, Pontificia Universidade Católica de Campinas, Campinas, SP BRASIL 13000-970 \&

Instituto de Quimica, Universidade Estadual de Campinas, Campinas, SP. BRASIL 13083-970

\begin{abstract}
The hydrolysis of 1 ithium p-nitrophenyl ethyl phosphate (LIPNEF) was studied at $259,35 \%$ and $459 \mathrm{C}$ by spectrophotometric techniques in the presence of micelles of cetyltrimethylammonium bromide (CTAB), sodium hydroxide and salt. The concentraion of $\mathrm{NaOH}$ used varied from 0,050 to $5,0 \mathrm{OH}$. and the $\mathrm{NaCl}$ ranged from 0,0050 to $0,030 \mathrm{M}$. Pseudo-first order rate constants $\left(k_{\psi}\right)$ and second order rate constants $\left(k_{2}\right)$ and activation parameters such as $E_{a}, \Delta H^{\neq}, \Delta G \neq$ and $\Delta S \neq$ were measured. The system was also studied by tensiometric, viscosity and quasi-elastic light scattering methods. At low concentrations of $\mathrm{NaOH}$ (below $0,55 \mathrm{M}$ ), the reaction can be explained in terms of conventional models of micellar catalysis, including the pseudo-phase ion exchange model. For higher concentration of $\mathrm{NaOH}$, conventional models of micellar catalysis are not applicable. In fact, at high hydroxide concentration, the system no longer contains micelles but liquid crystalline mesophases and a model analogous to phase transfer catalvsis aboears to be more aoorooriate.
\end{abstract}

\section{RESUMO}

A hidrölise do littio p-nitrofenil etil fosfato (LiPNEF) foi estudada a 250,359 e $450 \mathrm{C}^{2}$ por métodos espectroscōpicos na presença de micelas de brometo de cetiltrimetilamónio (CTAB), hidroxido de sódio e sal. A concentração de $\mathrm{NaOH}$ variou entre 0,050 e $5,00 \mathrm{M}$ e de $\mathrm{NaCl}$ entre 0,0050 e $0,030 \mathrm{M}$. Foram medidas constantes de velocidade de pseudo-primeira ordem ( $\left.k_{4}\right)$ e segunda orgem $\left(k_{2}\right)$ e parâmetros de ativação tais como $E_{q}, \Delta H \neq, \Delta G \neq$ e $\Delta S^{*}$. 0 sistema tambēm foi estudado por mētodos de tensiometria, viscosidade e espalhamento quase-elastico de luz.. A concentrações baixas de $\mathrm{NaOH}$ (menos de $0,55 \mathrm{M}$ ) a reação pode ser explicada em termos termos de modelos convencionais de catalise micelar, inclusive - modelo de troca ionnica. Para concentrações mais elevadas de $\mathrm{NaOH}$, os modelos convencionais não são aplicāveis. De fato, a concentrações elevadas de $\mathrm{NaOH}$, o sistema não contëm mais micelas, mas mesofases líquido-cristalinas e um modelo anălogo à catälise por transferēncia de fase parece ma is adequado.

KEYWORDS: Micellar Catalysis, Phosphate Esters, Pseudo Phase Ion Exchange Model, Cetyltrimethylammonium Bromide-CTAB.

* Author to whom correspondence should be addressed at PUCRS. 
SOUTH. BRAZ. J. CHEM., Vol.4 Nº, 1996.

60

Nicellar Catalysis and the PPIE Model

\section{INTRODUCTION}

The present paper deals with the hydrolysis of lithium p-nitrophenyl ethyl phosphate (LiPNEF) in aqueous solutions in the presence of micelles or other aggregates of cetyltrimethylammonium bromide (CTAB) and varying concentraions of $\mathrm{NaOH}$ and $\mathrm{NaCl}$. The reaction under consideration is illustrated below.<smiles>CCOP(=O)(O)Oc1ccc([N+](=O)[O-])cc1</smiles><smiles>CCOP(=O)([O-])O[C-]c1ccc([N+](=O)[O-])cc1</smiles>

The organophosphorus compound under consideration (LiPNEF) is a common pesticide related to Paroxon and Paratition that have a wide use in agriculture.1,2

In previous studies we have shown that the hydrolysis of dir and tri-substituted phosphate esters is catalyzed by micelles of cetyltrimethylammonium bromide $\left[\mathrm{C}_{16} \mathrm{H}_{33} \stackrel{+}{\mathrm{N}}\left(\mathrm{CH}_{3}\right)_{3} \mathrm{Br}\right.$, CTAB] and also by micelles of $N, N$-dimethy $1-N$-hydroxyethyldodecylammonium bromide, [DHEDAB, $\mathrm{n}-\mathrm{C}_{12} \mathrm{H}_{2} 5^{\stackrel{+}{N}}\left(\mathrm{CH}_{3}\right)_{2} \mathrm{CH}_{2} \mathrm{CH}_{2} \mathrm{OH} \mathrm{Br}-$ ] and $N, N$-dimethyl-N-hydroxyethylcetylammonium bromide,

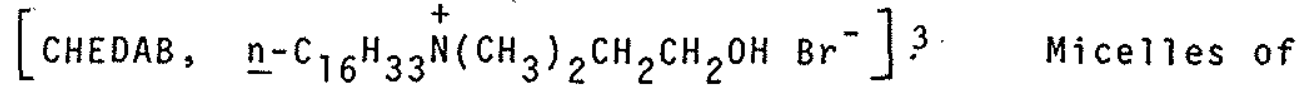
DHEDAB and CHEDAB are excellent catalysts for the hydrolysis of both LiPNEF and p-nitrophenyl diphenyl phosphate in the presence of $\mathrm{OH}^{-}$, with over 300-fold rate enhancement for 
SOUTH. BRAZ. J. CHEM., Vol.4 No4, 1996

the hydrolysis of the triaryl phosphate in the presence of CHEDAB. The catalytic effect and the dependence of the reaction rate on hydroxide ion concentration has been explained in terms of nucelophilic participation of the alkoxide ion of DHEDAB and CHEDAB, with $\mathrm{pK}_{\mathrm{a}}$ of 12.4 and 12.9 , respectively for the ionization of the hydroxyl group. For reactions with fluoride ion, the hydroxy-substituted surfactants are no better catalysts than the corresponding alkyltrimethylammonium bromides, suggesting that electrophilic catalysis is relatively unimportant. Cetylpyridinium bromide $[\mathrm{CPBr}$, $\left.{ }_{\mathrm{NC}}^{+} \mathrm{H}_{33} \mathrm{Br}^{-}\right]$has approximately the same effect as CTAB at low hydroxide concentration and a slightly more pronounced effect with fluoride ion. Zwitterionic surfactants such as lauryl carnitine chloride (LCCI) and palmityl carnitine chloride (PCCI) have little effect on the rate of hydrolysis of LIPNEF. 4,5

The addition of primary amines increased the rate of reaction in the presence of CTAB and CHEDAB for the triarylphosphate, but much of the increase was due to attack by amine on the aryl group. In the absence of micelles, amines increased the overall rate of the reaction by attacking the aryl group without markedly catalyzing hydrolysis.

The micellar catalyzed oxidative cleavage of a carboncarbon bond in Dicofol ${ }^{7}$ and the micellar catalyzed dehydrochlorination of $1,1,1-t r i c h l o r o-2,2-b$ is ( $p-c h l$ orophenyl)ethane (DDT) and some of its derivatives have also been the subject of our investigations. ${ }^{8,9}$ 
SOUTH. BRAZ. J. CHEM., Vol.4 Nº, 1996

In more recent studies we have reported results obtained for the hydrolysis of $p$-nitrophenyl diphenyl phosphate in aqueous solutions in the presence of micelles of diethylheptadecylimidazolinium ethyl sulfate (DEHIES) and CTAB, sodium hydroxide and dimethyl sulfoxide (DMSO) and analyzed the effect of internal pressure of the medium, dielectric constant, donor number and polarity of the solvent and the effect of DMSO on micellization.10-12

\section{EXPERIMENTAL PROCEDURE}

Materials. Lithium p-nitrophenyl ethyl phosphate (LiPNEF) was prepared from diethyl phosphate and sodium p-nitrophenoxide using $L i C l$ in dry acetone, followed by precipitation with diethyl ether. 13,14

The surfactant cetyltrimethylammonium bromide (CTAB) was purchased from Aldrich Chemical Company, Milwaukee, Wisconsin, USA. It was recrystallized from ethanol three times and dried under vacuum. $\mathrm{NaOH}$ and $\mathrm{NaCl}$ were supplied by Merck do Brasil, S.A., Rio de Janeiro and were of analytical reagent grade. The water was deionized and distilled. kinetics. The hydrolysis of LiPNEF was studied spectrophotometrically measuring the rate of appearance of the p-nitrophenoxide ion at $4030 \stackrel{\circ}{\mathrm{A}}:$. A varian 634 spectrophotometer, equipped with a water-jacketted cell compartment was used. The pseudo-first order rate constant $\left(k_{\psi}\right)$ was determined at $25^{\circ}, 35^{\circ}$ and $45^{\circ} \mathrm{C}$ by graphical methods using the integrated form of the rate equation. The second order 
SOUTH. BRAZ. J. CHEM., Vol.4 N4, 1996

L.G. Ionescu, D.A.R. Rubio \& E.F. De Souza

rate constant $\left(k_{2}\right)$ was calculated from $k_{\psi}$ and the hydroxide ion concentration. The activation parameters were determined from measurements of the reaction rate at three different temperatures using appropriate equations. ${ }^{10}$

The experimental procedures for quasi-elastic light scattering and viscosity measurements have been described elsewhere in the literature. 15,16

\section{RESULTS AND DISCUSSION}

Some typical experimental results obtained for the pseudo first order rate constant $\left(k_{\psi}\right)$ for the hydrolys is of LiPNEF at 2500 are illustrated in Figure 1 . The values of $k_{\psi}$ for low concentrations of $\mathrm{NaOH}$ (less then $0,55 \mathrm{M}$ ) decrease as a function of concentration of $\mathrm{NaCl}$, an observation typical of micellar catalyzed reactions. ${ }^{3}$ At higher concentrations of $\mathrm{NaOH}$ (more than 1,00 M), however, the experimental values of $k_{\psi}$ are essentially constant and are not affected by the addition of salt, illustrating the more pronounced electrolyte effect of the hydroxide ion.

Figure 2 shows some typical results obtained for the second order rate constant $k_{2}\left[k_{2}=k_{\psi} /\left(\mathrm{OH}^{-}\right)\right]$as a function of $\mathrm{NaCl}$ concentration for fixed low concentrations of sodium hydroxide. It can be seen that the second order rate constant is highly dependent and decreases in the presence of salt. 
SOUTH. BRAZ. J. CHEM., Vol.4 Nº, 1996

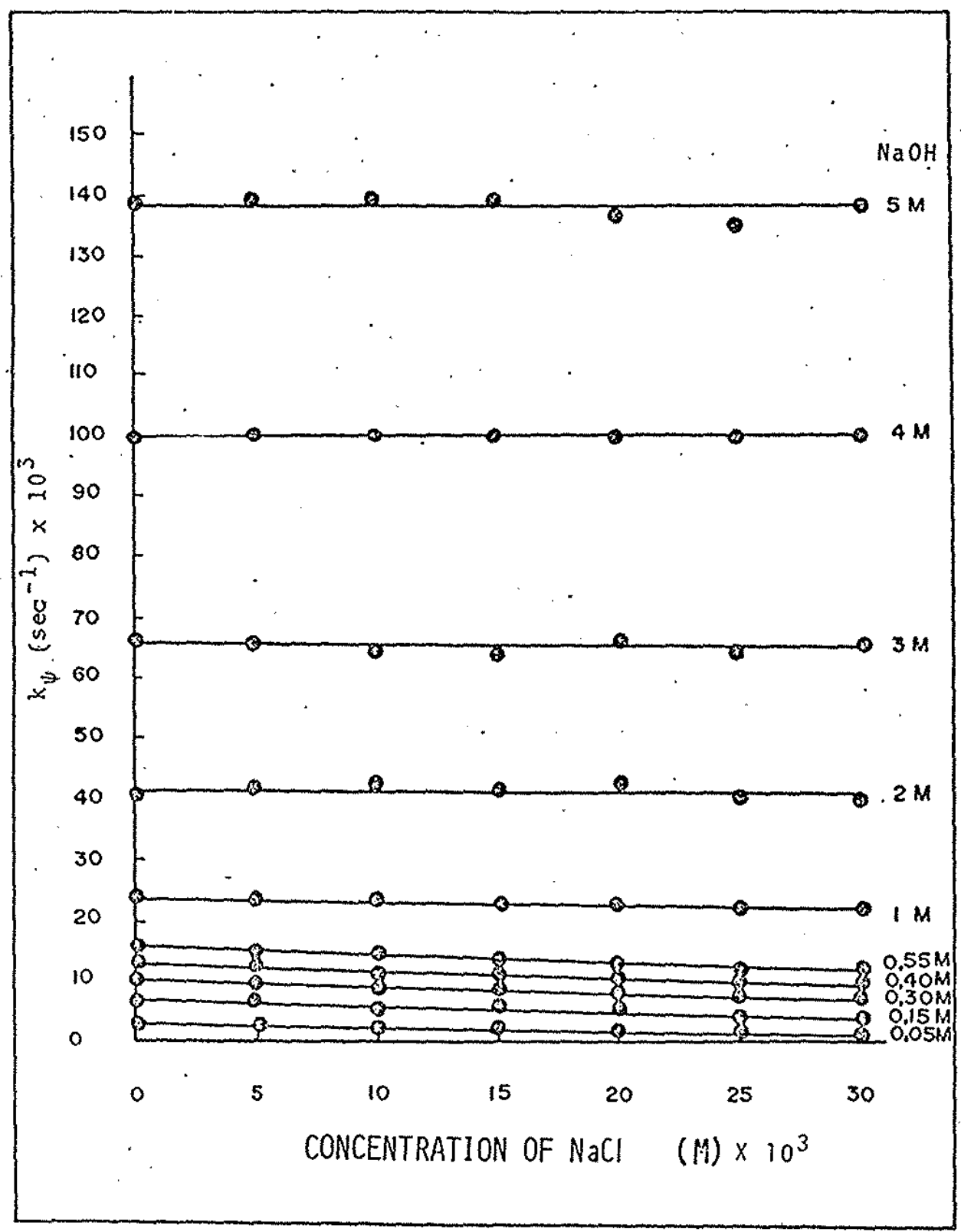

FIE, 1 . PLOT OF THE PSEUDO-FIRST ORDER RATE CONSTANT (k. $)$ VERSUS THE COHCENTRATION OF SALT FOR THE HYDROLYSIS OF LIPNEF AT $25^{\circ} \mathrm{C}$ IN THE PRESENCE OF $0.0088 \mathrm{M}$ CTAB AND DIFFERENT CONCENTRATIONS OF SODIUR: HYDROXIDE. 
SOUTH. BRAZ. J. CHEM., Vol.4 N4, 1996.

L.G. Ionescu, D.A.R. Rubio \& E.F. De Souza

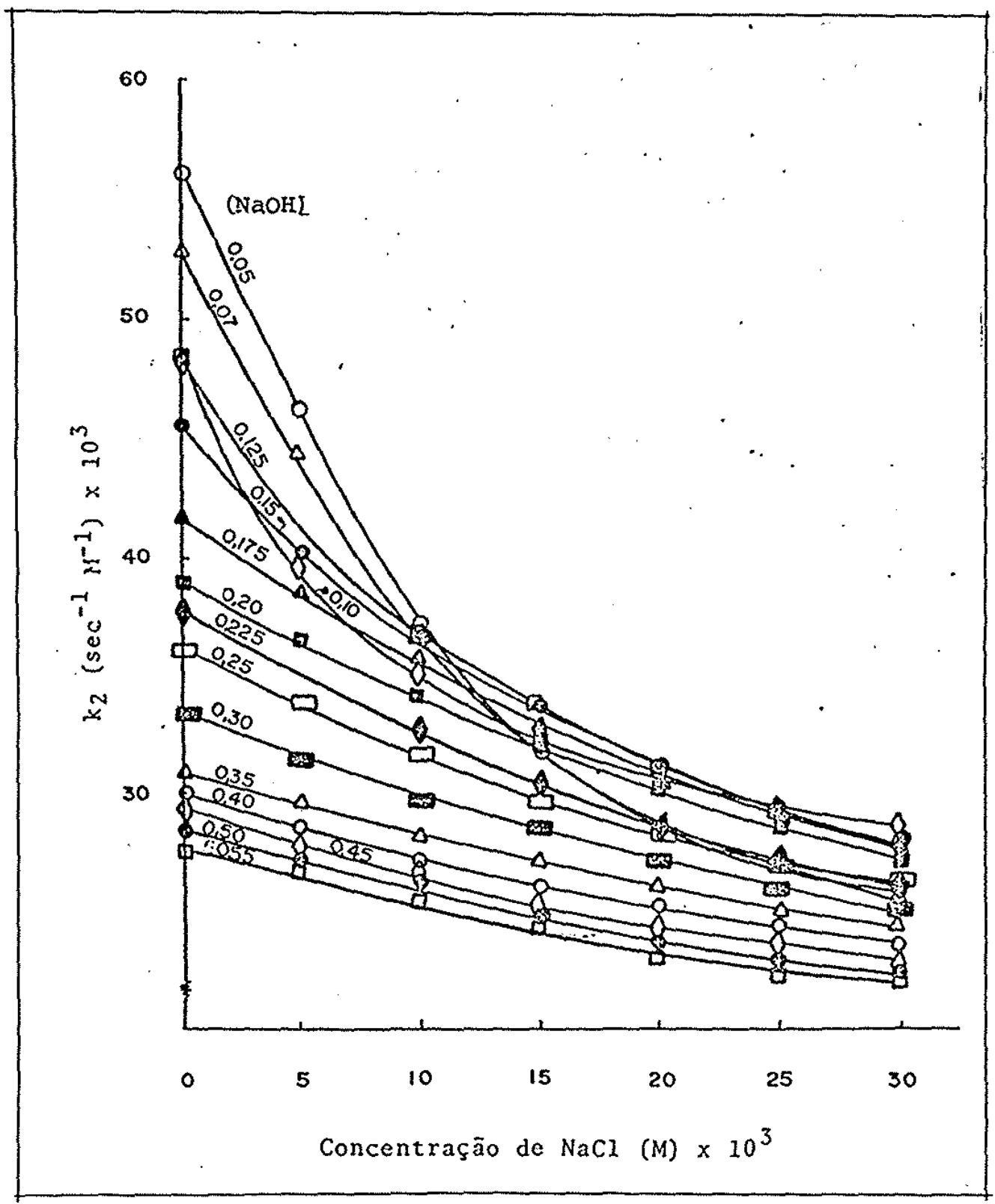

FIG. 2. VARIATION OF THE SECOND ORDER RATE CONSTANT $\left(\mathrm{k}_{2}\right)$ VERSUS THE CONCENTRATION OF SALT FOR THE HYOROLYSIS OF LIPNEF AT 25OC IN THE PRESENCE OF $0,0088 \mathrm{M}$ CTAB AND LOW CONCENTRATIONS OF SODIUM HYDROXIDE. 


\section{SOUTH. BRAZ. J. CHEM., Vol.4 Nº, 1996.}

Figure 3 illustrates the variation of the second order rate constant $k_{2}$ as a function of $\mathrm{NaCl}$ concentration for fixed high and low concentrations of $\mathrm{NaOH}$. It can be clearly noted: that for high concentrations of $\mathrm{NaOH}$ (above $1,00 \mathrm{M}$ ) the values of $k_{2}$ are practically constant and do not depend on the presence of salt.

Figure 4 shows the dependence of the second order rate constant $k_{2}$ on the hydroxide ion concentration in the absence of salt and the presence $0,0088 \mathrm{M} \mathrm{CTAB}$. The experimental values of $k_{2}$ decrease exponentially at low concentrations of $\mathrm{NaOH}$ $(0,010$ to $2,00 \mathrm{M})$, reach a minimum at $2,00 \mathrm{M}$ and increase at higher concentrations of $\mathrm{NaOH}(2,00$ to $5,00 \mathrm{M})$.

Figure 5 illustrates some typical results obtained for the diffusion coefficient (D) of the CTAB- ${ }_{2} \mathrm{O}-\mathrm{NaOH}$ ternary system at $250 \mathrm{C}$ by means of quasi-elastic light scattering. It is interesting to note the presence of three different types of behavior of the diffusion coefficient $D$, indicating the presence of spherical micelles (positive slope part), elliptical micelles (zero slope) and stepladder growth with gelatinous and liquid crystalline mesophases (negative slope part). This observation is consistent with viscosity and surface tension measurements for the same system.

The activation parameters were determined from experimental values of $k_{\psi}$ at 250,350 and $450 \mathrm{C}$ in the presence and absence of salt at different concentrations of $\mathrm{NaOH}$. Some representative are summarized in Tables I and II. 
SOUTH. BRAZ. J. CHEM., Vol.4 N²4, 1996

L.G. Ionescu, D.A.R. Rubio \& E.F. De Souza

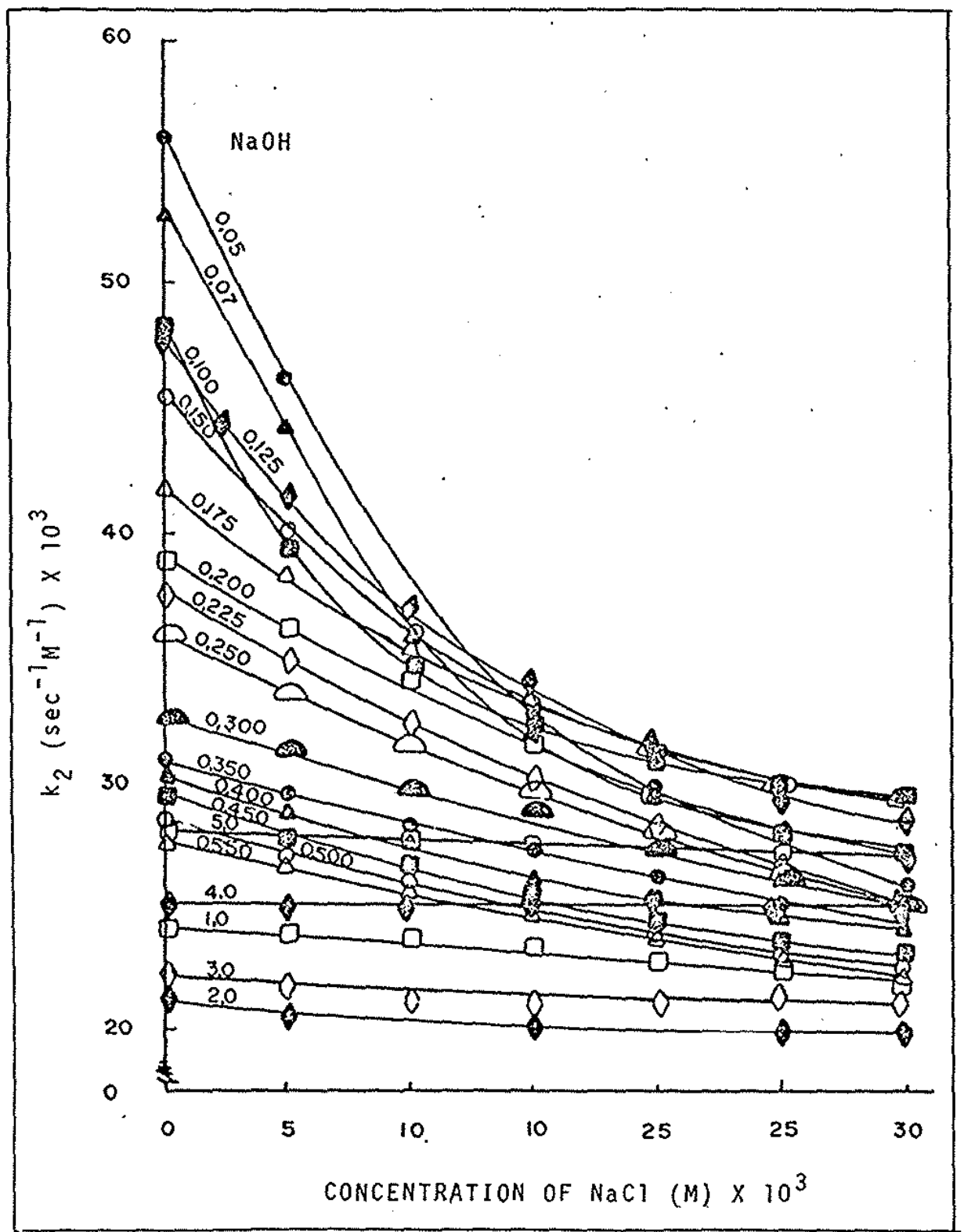

FIG. 3. VARIATION OF THE SECOND ORDER RATE CONSTANT (k 2$)$
VERSUS THE CONCENTRATION OF SALT FOR THE HYDROEYSIS OF LIPNEF AT 25:C IN THE PRESENCE OF $0,0088 \mathrm{M}$ CTAB AND DIFFERENT FIXED CONCENTRATIONS OF SODIUM HYDROXIDE. 
SOUTH. BRAZ. J. CHEM., Vol.4 N4, 1996.

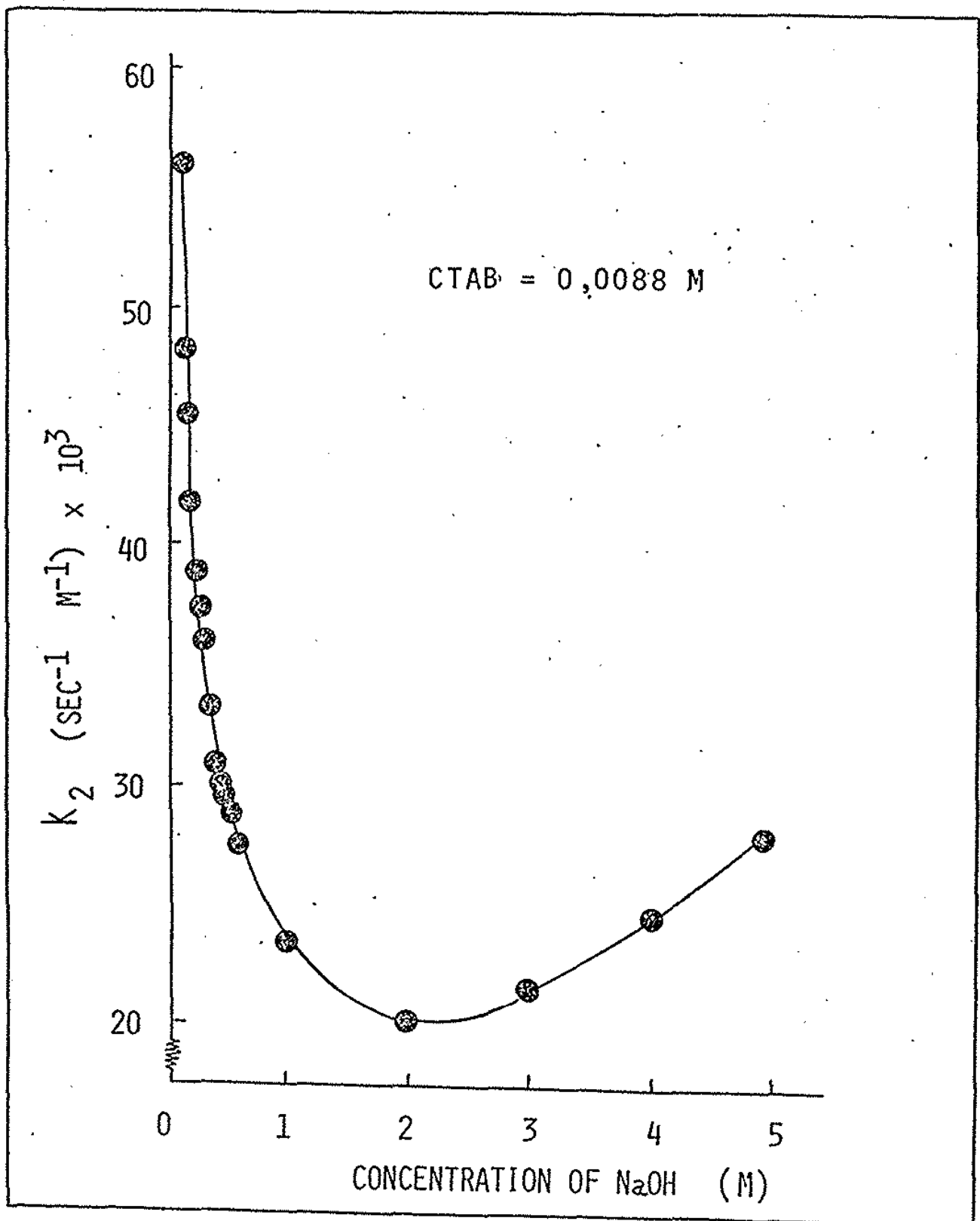

FIG. 4. VARIATIOH OF THE SECOND ORDER RATE CONSTANT $\left(k_{2}\right)$ AS A FUNCTION OF SODIUM HYDROXIDE CONCENTRATION FOR THE HYDROLYSIS OF LIPNEF AT $25^{\circ} \mathrm{C}$ IN THE ABSENCE OF SALT. 
SOUTH. BRAZ. J. CHEM., Vol.4 No $4,1996$.

L.G. Ionescu, D.A.R. Rubio \& E.F. De Souza

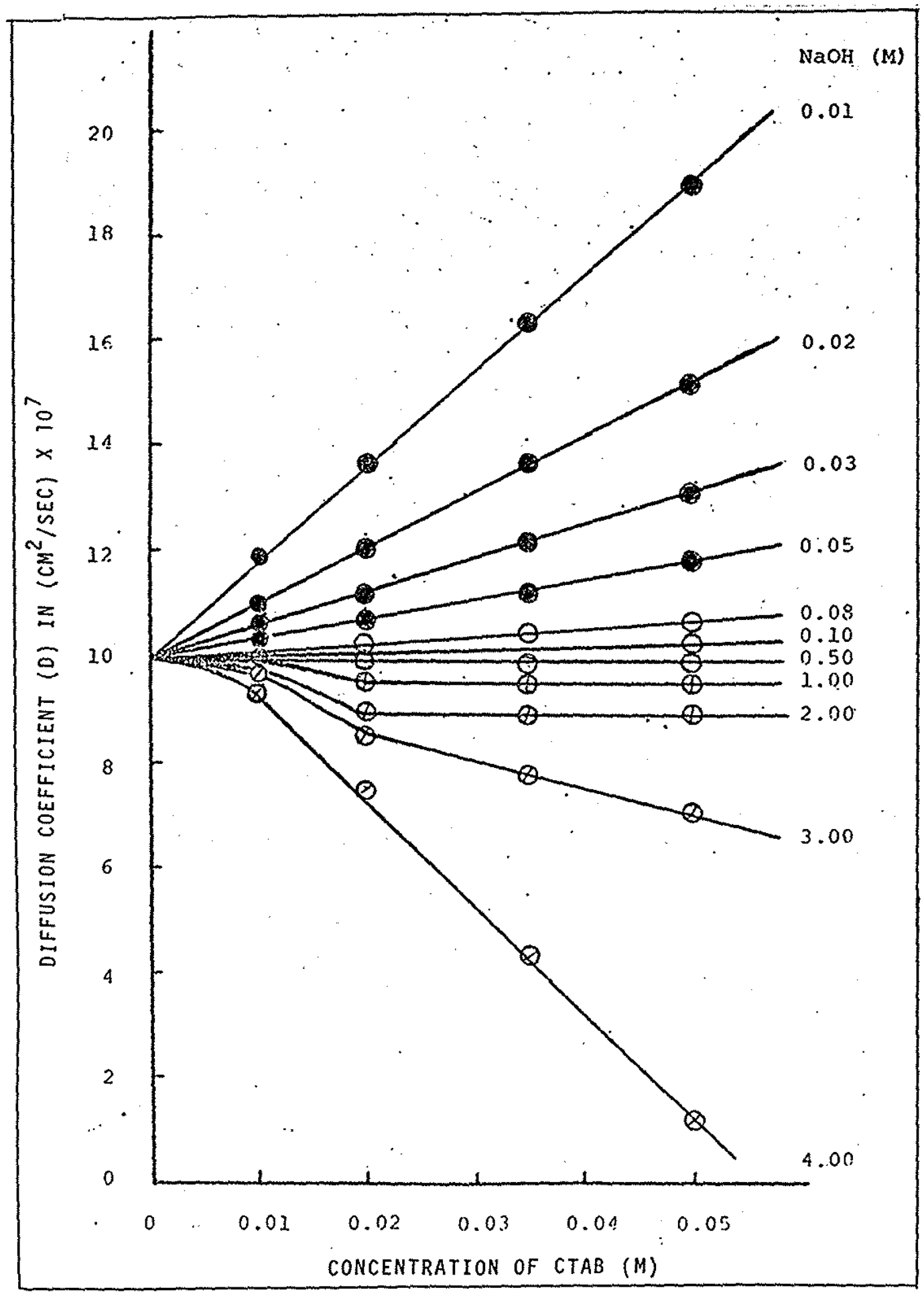

FIGURE 5. DIFFUSION COEFFICIENT (D) FOR THE CETYLTRIMETHYLAMMONIUM BROMIDE-HATER-SODIUM HYDROXIDE TERNARY SYSTEM AT $25^{\circ} \mathrm{C}$. 
SOUTH. BRAZ. J. CHEM., Vol.4 N4, 1996

TABLE I. ACTIVATION PARAMETERS FOR THE HYDROLYSIS OF LIPNEF IN THE PRESENCE OF $0,0088 \mathrm{M}$ CTAB, 0,030M NaCl AND DIFFERENT CONCENTRATIONS OF NaOH.

\begin{tabular}{rcccc}
\hline $\mathrm{NaOH}$ & $\mathrm{E}_{\mathrm{a}}$ & $\Delta \mathrm{H}^{\neq}$ & $\Delta \mathrm{G}^{\neq}$ & $\Delta \mathrm{S}^{\neq}$ \\
$(\mathrm{M})$ & $(\mathrm{kcal} / \mathrm{mole})$ & $(\mathrm{kcal} / \mathrm{mole})$ & $(\mathrm{kcal} / \mathrm{mol})$ & $(\mathrm{e} . \mathrm{u})$. \\
\hline & & & & \\
\hline 0,05 & 14,7 & 14,1 & 21,4 & $-24,4$ \\
0,70 & 13,4 & 12,8 & 20,9 & $-27,2$ \\
1,00 & 10,2 & 9,58 & 20,7 & $-35,3$ \\
& 9,32 & 8,73 & 19,7 & $-36,7$ \\
\hline
\end{tabular}

TABLE II. ACTIVATION PARAMETERS FOR THE HYDROLYSIS OF LIPNEF IN THE PRESENCE OF $0,0088 \mathrm{M}$ CTAB, THE ABSENCE OF SALT AND DIFFERENT CONCENTRATIONS OF NaOH.

\begin{tabular}{ccccc}
$\mathrm{NaOH}$ & $E_{a}$ & $\Delta H^{f}$ & $\Delta G^{f}$ & $\Delta \mathrm{S}^{\neq}$ \\
(M) & $(\mathrm{kcal} / \mathrm{mole})$ & $(\mathrm{kcal} / \mathrm{mole})$ & $(\mathrm{kcal} / \mathrm{mole})$ & $(\mathrm{e} . \mathrm{u})$. \\
& & & & $\ldots$ \\
\hline & & & & \\
0,05 & 14,2 & 13,6 & 21,5 & $-26,4$ \\
0,10 & 13,6 & 13,0 & 20,6 & $-25,6$ \\
1,00 & 11,8 & 11,2 & 19,9 & $-29,4$ \\
& 11,2 & 10,6 & 19,6 & $-30,4$ \\
\hline
\end{tabular}

In general, for low concentrations of sodium hydroxide, the activation parameters are comparable to others obtained for similar reactions catalyzed by micelles! ${ }^{11}$ and they decrease as a function of $\mathrm{NaOH}$. The addition of $\mathrm{NaCl}$ also causes a decrease. It thus appears that the presence of $\mathrm{NaOH}$ and $\mathrm{NaCl}$ lead to a more structured or ordered transition state. 
SOUTH. BRAZ. J. CHEM., Vol.4 No 4, 1996.

Most of the models proposed for micellar catalysis $17-22$ consider the partition coefficient for the substrate between the micellar and aqueous phase and the distribution of the reagents between the two phases. The hydrolysis of LiPNEF with hydroxide ion in the presence of CTAB may be considered a bimolecular reaction between $\mathrm{OH}^{-}$and the substrate. Since the concentration of $\mathrm{OH}^{-}$in the micellar phase is dependent on the concentration of bromide ion and surfactant, a quantitative treatment of the reaction rate must consider ion exchange on or near the micellar surface. For the reaction under consideration, the model proposed by Quina and Chaimo$v i c{ }^{21}$ reduces to Equation (I) that gives the theoretical dependence of the pseudo first order rate constant, $k_{\psi}$, as a function of the total hydroxide ion concentration, $(\mathrm{OH})_{T}$.

$$
k_{\psi}=\frac{\left[\begin{array}{ll}
k_{2 m} / \bar{V} k_{s} K_{O H / B r} & (B r)_{m} /(B r)_{W}+k_{2}^{0}
\end{array}\right](\mathrm{OH})_{T}}{\left(1+k_{S} C_{D}\right)\left[1+k_{O H / B r}(B r)_{m}(B r)_{W}\right]}
$$

where

$C_{D}=$ concentration of micellized detergent

$k_{\psi}=$ pseudo first order rate constant

$k_{2 m}=$ second order rate constant in the micellar phase

$k_{2}^{0}=$ second order rate constant in the aqueous phase

$\mathrm{K}_{\mathrm{OH} / \mathrm{Br}}=$ ion exchange constant

$K_{S}=$ binding constant for the substrate 


\section{SOUTH. BRAZ. J. CHEM., Vol.4 Nº, 1996}

$(B r)_{m}=$ concentration of $\mathrm{Br}^{-}$in micellar phase

$(\mathrm{Br})_{W}=$ concentration of $\mathrm{Br}^{-}$in aqueous phase

$(\mathrm{OH})_{\mathrm{T}}=\operatorname{total~} \mathrm{OH}^{-}$concentration

$\nabla=$ molar volume of the surfactant

With substrates such as lithium p-nitrophenyl ethyl

phosphate that are very insoluble in water and are solubilized by CTAB the expression for $k_{\psi}$ can be reduced to a simpler form given by Equation (II).

$$
k_{\psi}=\frac{k_{2 m}}{C_{D} \nabla}(O H)_{T} \frac{k_{O H / B r}(B r)_{m} /(B r)_{W}}{i+k_{O H / B r}(B r)_{m} /(B r)_{W}}
$$

The concentration of $\mathrm{Br}^{-}$in the micellar phase can be obtained using the following equations. (Eq.. III-VII) $)^{23}$

$$
A_{1}=C_{D}+C M C+K_{O H / B r}{ }^{(O H)} T+(1-\alpha) C_{D} K_{O H} / B r
$$

where

$$
\begin{aligned}
\text { CMC } & =\text { critical micellar concentration of CTAB } \\
\alpha & =\text { degree of ionization of the micelle } \\
(\mathrm{OH})_{m} & =\frac{\left(-\mathrm{A}_{1}\right)+\left[\left(\mathrm{A}_{1}\right)^{2}+4\left(1-\mathrm{K}_{\mathrm{OH} / \mathrm{Br}}\right) \mathrm{OH}_{\mathrm{T}} \mathrm{K}_{\mathrm{OH} / \mathrm{Br}}(1-\alpha) \mathrm{C}\right]^{1 / 2}}{2\left(1-\mathrm{K}_{\mathrm{OH} / \mathrm{Br}}\right)}
\end{aligned}
$$

where $(\mathrm{OH})_{\mathrm{m}}=$ concentration of $\mathrm{OH}^{-}$in micellar phase

$$
\begin{aligned}
& (B r)_{m}=(1-\alpha) C_{D}-(O H)_{m} \\
& (B r)_{w}=\alpha C_{D}+C M C+(O H)_{m}
\end{aligned}
$$


SOUTH. BRAZ. J. CHEM., Vol.4 Nº, 1996.

L.G. Ionescu, D.A.R. Rubio \& E.F. De Souza

We have calculated the theoretical values of $k_{\psi}$ for the reaction discussed above using various concentrations of $\mathrm{OH}^{-}$, $\nabla=0,371 /$ mole; $K_{0 H / B r}=0,08 ; \alpha=0,20$ and CTAB $=0,0088 \mathrm{M}$.

Table IIIsummarizes some parameters used for the calcuation of the pseudo first order rate constant $\left(k_{\psi}\right)$ and Table IV presents the experimental values of $k_{\psi}$ and values calculated for $k_{\psi}$ using the ion exchange model and different fixed concentrations of $k_{2 m}$.

Figure 6 illustrates plots of the experimental pseudo first order rate constant $k_{\psi}$ for the hydrolysis of LiPNEF at $250 \mathrm{C}$ versus the hydroxide ion concentration and calculated $k_{\psi}$ values using the ion exchange model and different values of $k_{2 m}$. As can be seen, there is some agreement between the experimental data and the theoretically calculated results only at lower concentrations of hydroxide ion.

Figure 7 illustrates the same results using an expanded scale for the hydroxide ion concentration in the range of 0,00 to $0,55 \mathrm{M}$, where there is good agreement between the experimental and calculated values of $k_{\psi}$.

Figure 8 shows a plot of the experimental pseudo first order rate constant $k_{\psi}$ for the hydrolysis of LiPNEF at $250 \mathrm{C}$ versus hydroxide ion concentration giving the best fit of the experimental data with the pseudo phase ion exchange model and using a value of $0,0035 \mathrm{~s}^{-1} \mathrm{M}^{-1}$ for $k_{2 \mathrm{~m}}$. 
TABLE IET.SOME PARAMETERS USED FOR THE CALCULATION OF THE PSEUDO FIRST ORDER RATE CONSTANT $\left(k_{\psi}\right)$ USING THE ION EXCHANGE MODEL.

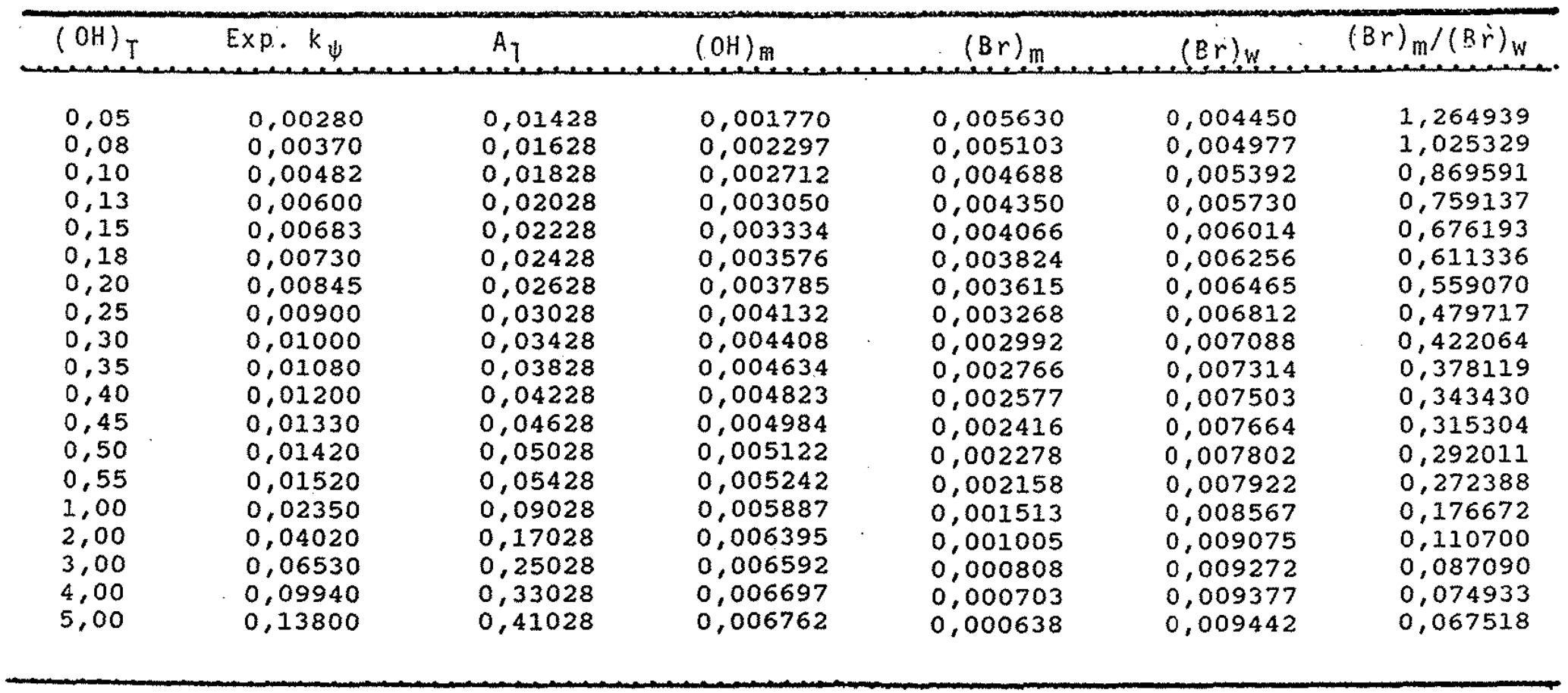

* All parameters are defined within the text. 
TABLE IV. CALCULATED PSEUDO FIRST ORDER RATE CONSTANTS ( $k \psi$ ) FOR DIFFERENT FIXED VALUES OF $k_{2 m}$ USING THE ION EXCHANGE MODEL.

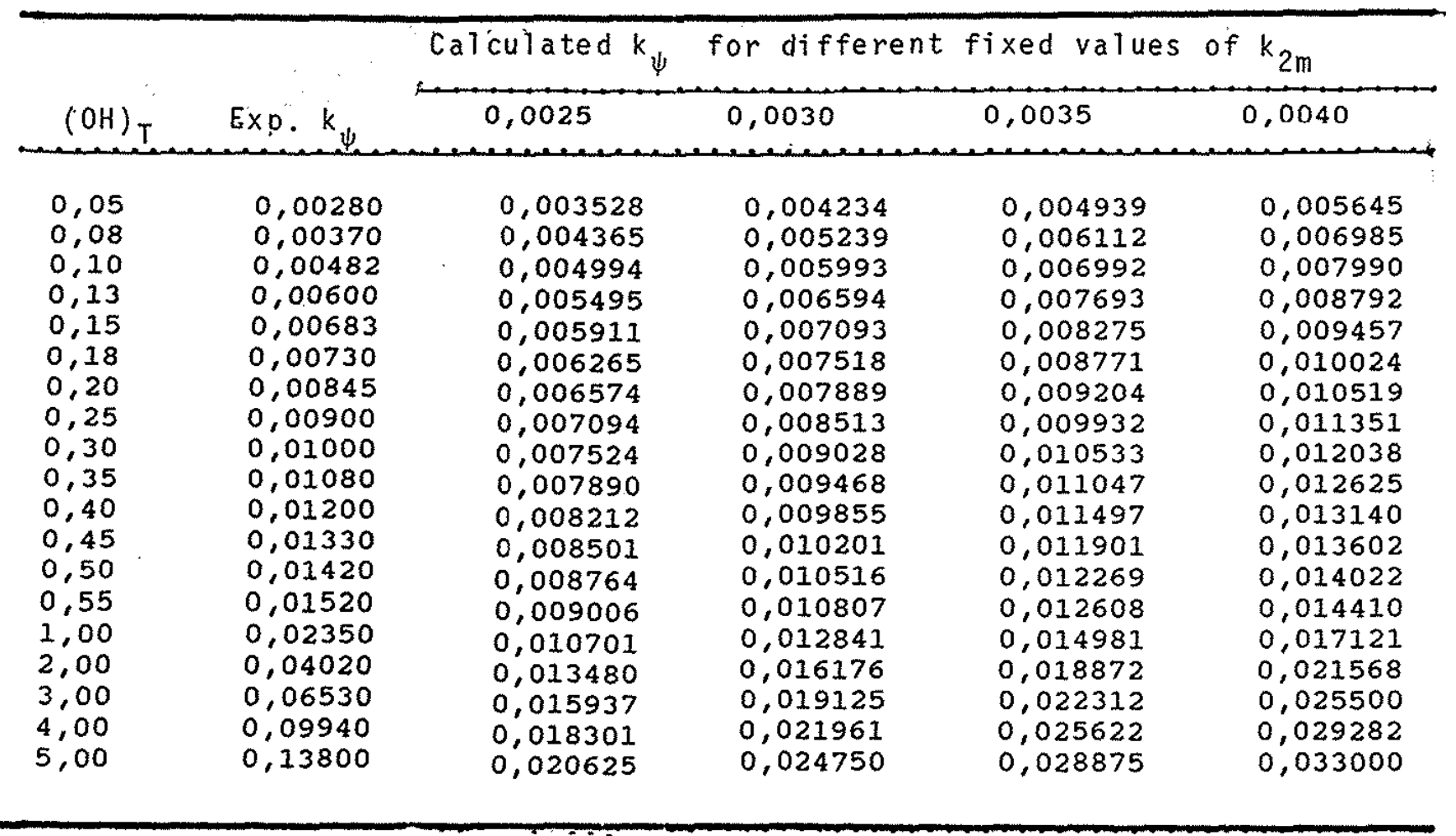

* All parameters are defined within the text. 


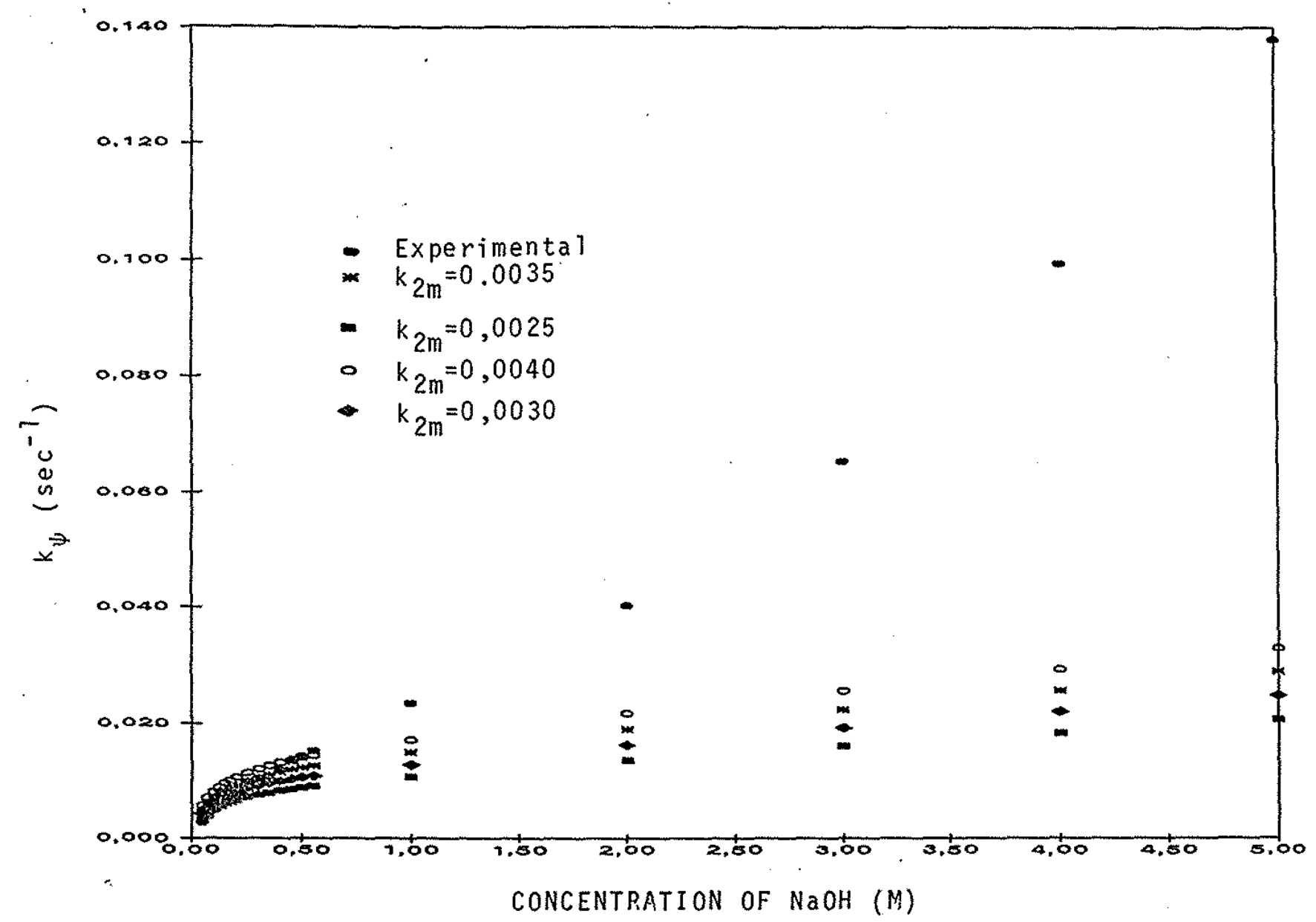

FIGURE 6. PLOTS OF THE EXPERIMENTAL PSEUDO FIRST ORDER RATE CONSTANT $K \Psi$ FOR THE HYDROLYSIS OF LIPNEF AT 25 OC VERSUS HYDPOXIDE ION CONCENTRATION AND FITS OF THE EXPERIMENTAL DATA HITH THE ION EXCHANGE MODEL USING DIFFERENT VALUES OF $\mathrm{k}_{2 \mathrm{~m}}$. 


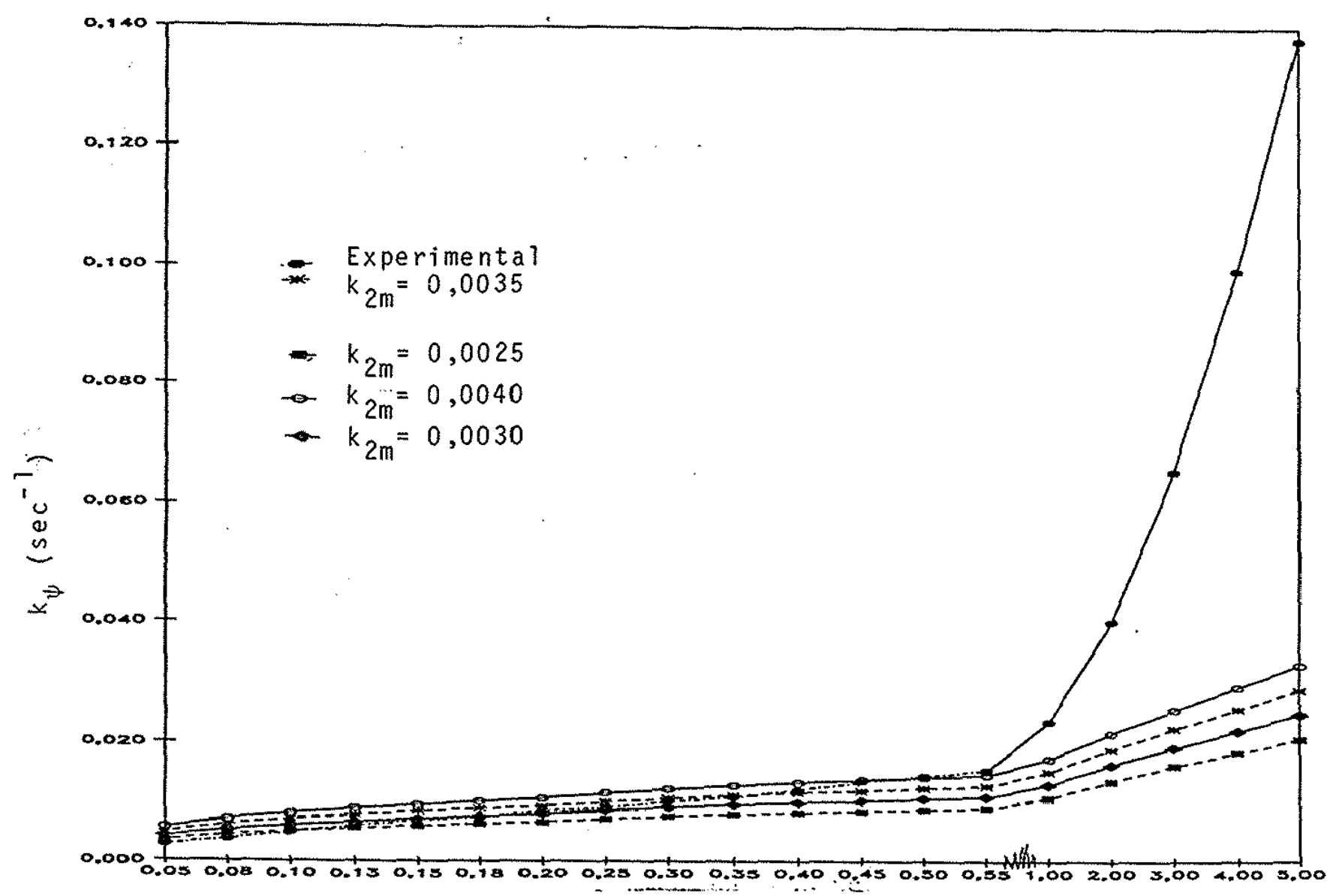

CONCENTRATION OF $\mathrm{NaOH}$ (M)

FIGURE 7. PLOTS OF THE EXPERIMENTAL PSEUDO FIRST ORDER RATE CONSTANT $K \Psi$ FOR THE HYDROLYSIS OF LIPNEF AT 25OC VERSUS HYOROXIDE ION CONCENTRATION AND FITS OF THE EXPERIMENTAL DATA WITH THE ION EXCHANGE MODEL USING DIFFERENT VALUES OF $k_{2 m}$ WITH AN EXPANDED SCALE AT LOW HYDROXIDE CONCENTRATION. 


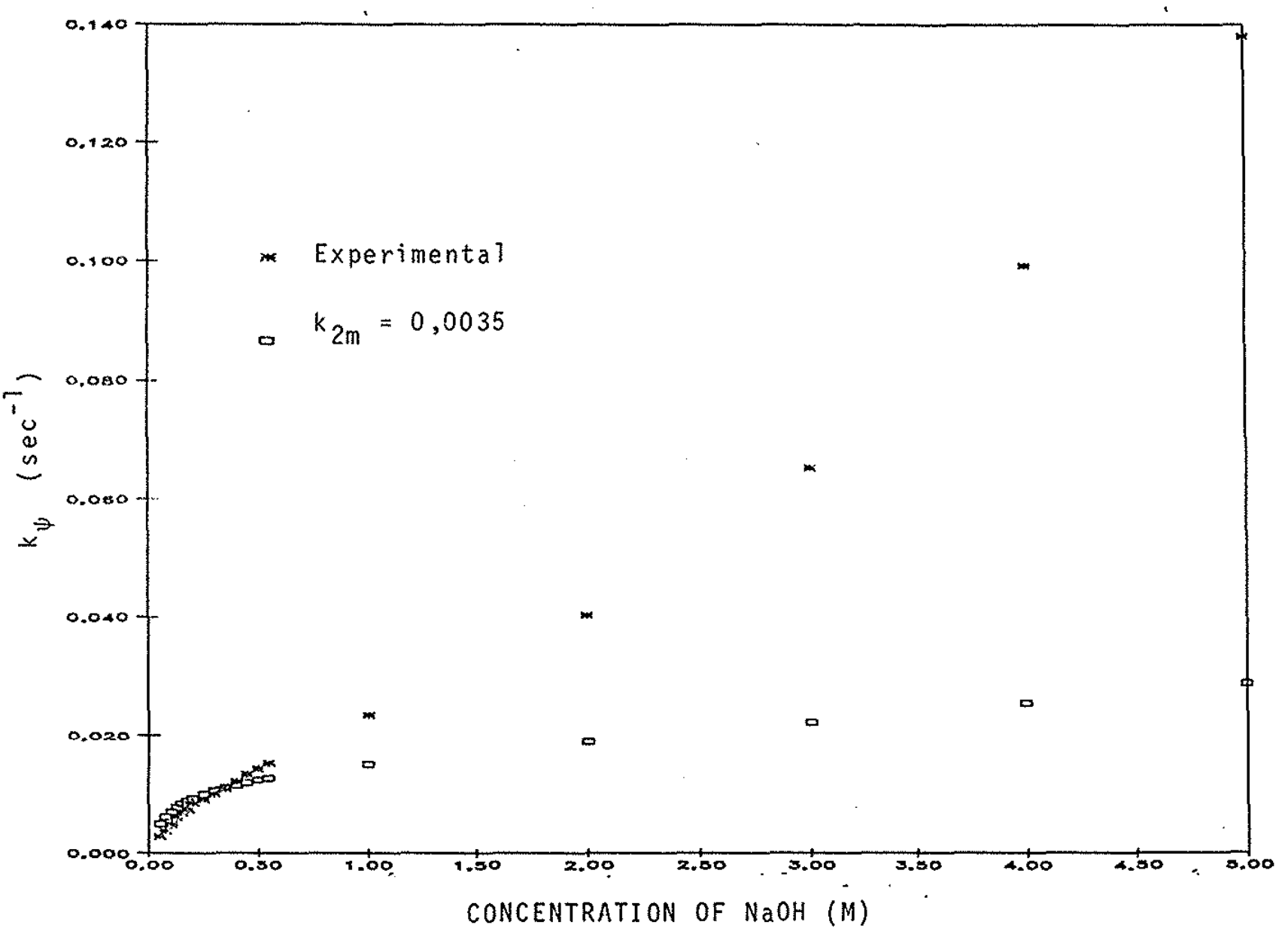

FIGURE 8. PLOT OF THE EXPERIMENTAL PSEUDO FIRST ORDER RATE CONSTANT K $\Psi$ FOR THE HYDROLYSIS OF LIPNEF AT 25OC VERSUS HYDROXIDE ION CONCENTRATI ON AND BEST FIT OF THE EXPERIMENTAL DATA WITH THE ION EXCHANGE MODEL USIG A VALUE OF $k_{2 m}$ OF $0,0035 \mathrm{~s}^{-1} \mathrm{M}-\mathrm{l}$. 
SOUTH. BRAZ. J. CHEM., Vol.4 N4, 1996.

L.G. Ionescu, D.A.R. Rubio \& E.F. De Souza

Attempts to explain the experimental results obtained for the hydrolysis of LiPNEF using the pseudo phase ion exchange models presented in the literature $18-23$ lead to failure of the models at higher hydroxide concentrations. Such failure at high hydroxide ion concentration has first been observed by Bunton, Romsted and Savel1i ${ }^{24}$ and by Lapinte and Viout ${ }^{25}$. The limitation of these models is not surprising, since they assume a constant micellar structure and involve partitioning of the substrate and the reactant between the aqueous and micellar phases and a fixed number of sites. All of them assume a closed thermodynamic system for a case when the kinetics under consideration may be more similar to flow kinetics, particularly when the micelles change in form, size and shape or undergo transitions to liquid crystalline mesophases.

More recent models, such as those proposed by D.G. Hall 26 that considers the transition state and by Bunton and Moffatt 27,28 that suggest a Coulombic Model and use the Poisson-Boltzmann Equation take into considerations some of shortcomings mentioned above.

Bunton, Romsted and Saye $11 i^{24}$ in their paper that may be considered a major breakthrough im micellar catalysis, explained the discrepancy between the theoretical models and the experimental results by considering an additional reaction pathway across the micellar boundary at the shear surface between the Stern and the Gouy-Chapmnan layers of the micelle. We have 


\section{SOUTH. BRAZ. J. CHEM., Vol.4 Nº, 1996}

suggested that conceptually this interfacial boundary or micelle-water interface, as it has been called, should not be very different from the interface present in systems where phase transfer catalys is is taking place. $8,9,29,30$

Quasi elastic light scattering, viscosity and surface tension studies of the $\mathrm{CTAB}-\mathrm{H}_{2} \mathrm{O}-\mathrm{NaOH}$ (See Figure 5) and CTAB- $\mathrm{H}_{2} \mathrm{O}-\mathrm{NaCl} 15,16$ systems clearly indicate changes in size and shape of the CTAB micelles and formation of liquid crystalline mesophases as a function of electrolyte concentration.

Consideration of the kinetic results presented above in light of the structural changes occuring in the system excludes the theoretical pseudo phase ion exchange models presented in the literature ${ }^{18-23}$ for concentration of $\mathrm{OH}^{-}$ above $0,55 \mathrm{M}$. Changes in size, form, shape of the CTAB micelle and formation of Iamellar and liquid crystalline mesophases are not taken into account in any of these models. 18-23 For solutions of surfactants containing higher concentrations of electrolyte, serious consideration should be given to models more akin to phase transfer catalysis or liquid crystalline catalysis. Samori and his collaborators haye described liquid crystalline catalysis by smectic $B$ solvents 31,32 and Ramesh and Labes have investigated the control of reaction kinetics by manipulation of micellar size and shape 33,34 and the influence of disc-rod-sphere transitions in nematic lyotropics on a unimolecular isomerization reaction. 
SOUTH. BRAZ. J. CHEM., Vol.4 N4, 1996.

L.G. Ionescu, D.A.R. Rubio \& E.F. De Souza

\section{REFERENCES}

1. F.A. Gunther and J.D. Gunther, "Chemistry of Pesticides", Springer Verlag, New York, 1971.

2. C. Salazar, G. M. Souza and C.P.D. Silva, "Manual de Inseticidas e Acaricidas - Aspectos Toxicológicos", Pelotas, RS, Brazil, 1976.

3. C.A. Bunton and L.G. Ionescu, J.Amer. Chem. Soc., 95, 2912 (1973).

4. L.G. Ionescu and D.A. Martinez, J. Colo. Wyo. Acad. Sci., $7(5)$, i $3(1974)$.

5. L.G. Ionescu, BuzZ. N. Mex. Acad. Sci., 24(2), 65 (1973).

6. C.A. Bunton, S. Diaz, J.M. Hellyer, I. Ihara and L.G. Ionescu, J. Org. Chem., 40, 2313 (1975).

7. F. Nome. E.W. Schwingel and L.G. Ionescu, J. Org. Chem., 45,705 (1980).

8. F. Nome, A. Rubira, C. Franco and L.G. Ionescu, J. Phys. Chem. 86, 1181 (1982).

9. L. G. Ionescu and F. Nome in "Surfactants in Solution", K.L. Mittal and B. Lindman, Eds., Plenum Press, New York, 1984, Vol. 2, p. i 1107 .

10. L. G. Ionescu and E. F. De Souza, South. Braz. J. Chem., Z, $77($ ig93).

11. L. G. Ionescu and E. F. De Souza, "Surfactants in Solution", K.L. Mittal and A.K. Chattopadhyay, Eds., Marcel Dekker Inc., New York, 1996, Vol.64, p.123.

12. L. G. Ionescu and E. F. De Souza, South. Braz. J. Chem., 3. $63(1995)$.

13. A. M. Roos and J. Toet, Rec. Trav. Chim.,77, 946 (1958).

14. A. S. Kirby and M. Jounas, J. Chem. Soc., B, 1165 (1970).

15. L. G. Ionescu, Quimica Nova, 8(3), 191 (1985).

16. L. G. Ionescu, T.H.M. Do Aido and B.J. Kid, Bol. Soc. Chil. Quim., 35, 105 (1990).

17. J. H. Fendler and E. J. Fendler, "Catalysis in Micelzar and Macromoleculax Systems", Academic Press, New York, 1975.

18. I. V. Berezin, K. Martinek and K. Yatsimirskii, Russ. Chem. Rev., 42,787 (1973).

19. K. Martinek, A. K. Yatsimirskii, A. V. Levasov and I. V. Berezin, in "Miceilization, Solubilization and Microemuisions", K. L. Mittal, Editor, Plenum Press, New York, 1977, Vol. 2, p. 489 . 


\section{SOUTH. BRAZ. J. CHEM., Vol.4 Nº, 1996.}

20. L. S. Romsted, in "Micellization, Solubilization and Microemulsions", K. L. Mittal, Editor, Plenum Press, New York, 1977, Vol. 2, p. 509.

21. F. Quina and H. Chaimovich, J. Phys. Chem., 83,1844 (1979).

22. N. Funasaki, J. Phys. Chem., 83, 1998 (1979).

23. C. Otero and E. Rodenas, Can. J. Chem., 63,2892 (984).

24. C. A. Bunton, L. S. Romsted and G. Savelli, J.Amer.Chem. Soc., 202, 1253 (1979).

25. C. Lapinte and P. Viout, Tetrahedron, 35, 1931 (1979).

26. D. G. Hall, J. Phys. Chem., 92, 4287 (1987).

27. C. A. Bunton and J. R. Moffatt, J. Phys. Chem.,89, 4166 (1985)

28. C. A. Bunton and J. R. Moffatt, J. Phys. Chem., 90, 538 $(1986)$.

29. L. G. Ionescu and D.A. R. Rubio, supl. Cienc. Cult.,33(7), $463(1981)$.

30. L. G. Ionescu and D. A. R. Rubio, Arq. Biol. Tecnol., 24, 76 (1981).

31. P. De Maria, P. Mariani, F. Rustichelli and B. Samori, Mol. Cryst. Liq. Cryst., Z2Z, 115 (1984).

32. P. De Maria, A. Lodi, B. Samori, F. Rustichelli and G. Torquato, J. Amer. Chem. Soc., 206, 653 (1984).

33. V. Ramesh and M. M. Labes, J. Amer. Chem. Soc., 208, 4643 (1986).

34. V. Ramesh and M. M. Labes, J. Amer. Chem. Soc., 209, 3228 (1987). 